\title{
ART THERAPY: CREATIVITY FOR CURE
}

\author{
Yam Prasad Sharma*
}

\begin{abstract}
Art therapy is used for healing or treatment of some health problems. For such healing, arts like painting, sculpture, music, drama, dance and poetry are used. Art is related to creativity whereas therapy is related to cure, treatment and healing. Art therapy includes creation, appreciation and healing. Art therapy may help individuals manage and cope with mental health problems, physical pain, difficult emotions, feelings and experiences. It allows people to be free from anxiety and use their imagination for something positive. Art therapy is highly useful to solve mental health problem and disorder in behavior. Whenever other methods of treatment become ineffective, art therapy can be a main form of treatment. However, the power of art for treatment has been ignored in our context. If the domain of art is linked to medical treatment, the cure of the disease can be easier. This attempt may add new dimensions in the field of treatment and healing. This article attempts to elaborate the concept of art therapy, how it can be applied in healing and various types of art therapies.
\end{abstract}

Key words: Art therapy, creativity, catharsis, aesthetic pleasure, substitute gratification, dance therapy, drama therapy, music therapy, visual art therapy.

\section{INTRODUCTION AND OBJECTIVE}

The concept of art therapy was in practice even in the time of Aristotle, the Greek philosopher, though the term 'art therapy' was not used. Aristotle (2009) brought the concept of Catharsis, purgation or purification in relation to tragic drama. In tragic drama, the protagonist, generally the good character of high status falls down from its height because of some errors in his character. This tragic fall arouses pity and fear in the audience who identify with the tragic hero. Drama, art or artificial situation facilitates for the arousal of human emotions like pity and fear. As a result, the viewers get aesthetic pleasure and experience Catharsis. They feel refreshed having better health. In the same way, other art forms also help for the better life of the creator, readers and viewers.

Renaissance and Neoclassical art critics talk about the delight that art provides. Nineteenth century critic Pater (1992) states that arts and literature provide many invaluable gems to our life. Freud (1992)

* Dr. Sharma is lecturer in English, Lalitkala Campus, Kathmandu, TU. 


\section{ART THERAPY: CREATIVITY FOR CURE}

employed arts and literature for psychoanalysis of his patients and clients. He argues that suppressed desires can be sublimated in the form of arts. Arts provide substitute gratification. When we cannot fulfill our desire, we can be mentally disturbed and depressed. Arts can help us fulfill the unfulfilled and hidden desires. Langer (2009) says that arts can express the things that language cannot. Arts nurture our feelings. Arts can be linked to medical field, and they can be applied for the treatment of certain problems.

We can get relief from our painful feelings and emotions by playing with art materials like colors, canvas, clay, stones, pencil and papers. Agell (1982) remarks that "a flirtation with materials is not enough. Only a love affair with materials can lead to a wedding of felt experience and formed expression" (37). While Carson and Becker (2004) state that expressive therapies are integral parts of creativity in counseling. Creativity in counseling involves flexibility in responding clients with various techniques. It also encourages creativity within therapy. Carson and Becker (2004) emphasize that counselors need to be 'continually cultivating' and 'refining their own creativity' (114). Gil (1998), a renowned art therapist, remarks that in case of severely traumatized patient the therapist should introduce activities to assist the child transform the story into a more productive experience. Similarly, Pennebaker (1997) states that scribbling and writing can be effective in emotional reparation and in reducing pain in illnesses. Art therapy can be useful in reestablishing healthy attachments through sensory experiences, interactions, movement and other activities. According to Malchiodi (2003), art therapy repairs and reshapes attachment through sensory means and establishes new and more productive patterns. Johnson (1985) observes that art therapists 'have a powerful vision' and they have 'emerged for a reason' (238). They attempt to connect to the patient's experience and inner world. McNiff (1992) argues that imagination is the healing element inherent in all forms of self-expression and arts. Imagination guides for the theory and practice of creativity. Art therapy can be used in response to a wide range of disorders. Arts are also integrated within psychotherapy and psychological counseling. Art therapy techniques have made psychotherapy more effective.

Art therapy is particularly helpful if talking treatments, counseling and conversations are not effective. Arts make people smile. Art therapy may help the patients of schizophrenia, paranoia and related problems like mental disorder and psychosis. Many therapists find that art therapy helps patients to communicate issues in ways that talk therapy cannot do. So, many psychologists, counselors and health care professionals are using the methods of art therapy in their work with patients. 


\section{TYPES OF ART THERAPY}

Art is an umbrella term which includes painting, sculpture, architecture, music, drama, dance and poetry. However, sometimes, art is related only to visual arts like painting, sculpture and architecture. In this context, we take art with its wider significances and multiple genres. Four types of art therapy have been briefly discussed here:

- Dance therapy includes a range of different dance and movement techniques. Dance therapists encourage the clients to change their movements to help change the way they feel. For instance, if a person is feeling low and humiliated, he may shrink his body and hunch his shoulders and appear smaller than he really is. In such situation, the concerned therapist can encourage him to stand upright to increase his self-respect. Dancing helps individuals become aware of their feelings and emotions which they find difficult to talk about and feel more comfortable with their body. Dance therapy is helpful to remove negative feelings about one's body. It assists to relate oneself with the surroundings.

- Drama therapy is the use of drama for the treatment and healing. The therapy may provide relief from pain, suffering and anxiety. It emphasizes on emotional balance and personal development. This method helps the individuals tell their personal story to solve problems. It facilitates to achieve catharsis or purgation enriching the inner experience. The creative process helps understand the meaning of images by strengthening the ability of observation. Participation in drama increases the flexibility in the body and movement. Landreth (1991), a pioneer of play therapy, states that it is particularly true for young children that do not have the verbal or language skills necessary for reflection. Expression through a painting, play, role play or movement can be a rewarding experience for some individuals. Moreno (1923), the founder of psycho-drama, states that the use of enactment can restore the mental health of the patients.

Drama therapy exploits a range of different drama and theatre techniques like acting plays, role play, mime, movement of the body delivering speech, being director, managing light, making costumes and being the viewer. Both creation and appreciation are involved. You can be suffused by watching the drama. The therapists can study, analyze and tell a lot from what you have created and responded. The subject matter of your creation can help open up issues for conversation and discussion. They can disclose your thoughts, feelings and emotions out of your mind. Drama therapy can assist a patient to express oneself. Drama therapist 


\section{ART THERAPY: CREATIVITY FOR CURE}

also helps him explore painful things that have happened to him. A person can explore, understand and connect one's relationships with other people. This can help you address problems. For instance, if a person feels he is dominated by other person, he can become assertive and aggressive in the drama. Levine (1999) notes that 'imagination is the central concept which informs the understanding of the use of arts and play in therapy' (259).

- Music therapy includes listening to music, singing or playing a musical instrument. One can compose and create one's own music or play a piece of music that one enjoys. The music that he creates, plays or appreciates depends on the client's feeling and interest. To practice and enjoy music therapy, the patient need not be perfect and skillful to use musical instruments. It is not necessary to have any early experience of playing music. Music therapists watch how the client plays music. They listen to the music that the patient has created and try to understand his inner emotions and feelings. Therapists try to bring positive changes on the feelings of the concerned person. Music takes the patient in the adventurous journey, and when the he returns back, he can feel much better and refreshed.

Music therapy can help us to study and analyze painful feelings, experiences and memories that we find difficult to share with other people. This helps the person deal with difficult problems. The process facilitates for expressing ourselves. We can connect to other people and make positive relationships. In other words, music creates order in confusion, mess and chaotic situation. Music therapy uses music to bring positive changes in the psychological, physical, cognitive, or social functioning of individuals with health or educational problems.

- Visual art therapy exploits various art media like paint, canvas, stone, clay, chalk, wood, paper and photography to create artworks that express our inner emotions, feelings and experiences. One art form can relate to other art forms. One may inspire the other. Music, poetry or stories may inspire us to create visual images, symbols and shapes. The disturbed mind may be concentrated on the lines, colors, images, textures, brushstrokes, rhythm and shapes. Visual art therapy can help us understand our feelings and emotions, and the ways we can handle with the painful feelings. We can share and communicate through images and shapes that we could not do with language and verbal texts. Art therapists give importance to the integration of visual art activities in treatment plans and stress that a quick drawing or collage art can move a client ahead when talk therapy becomes ineffective. 
The objects, materials or things we use to make artworks can remind us of our bygone experiences. Colors, clay and canvas can stimulate us to disclose our wishes and interests. Clay is very helpful to adjust with our changing feelings because the shape of clay can be easily changed, transformed and modified. The images and subject matters of the photographs that we have taken and our choices can be related to our past memories and painful emotions. We can share our creative works with our close friends and relatives. When they appreciate our artworks, we can feel better. Our artworks can remind us of our progress and recovery. According to McNiff (1992), some therapists encourage client dialogues that include "talking to the painting". The things which are difficult to express in words can be expressed through visual arts. Goodenough (1926) explored children's drawings to trace the cognitive development.

To use art therapy effectively, it is expected that a therapist should be aware about essential qualities and aspects of drama, visual art, music, dance and poetry. Fleshman \& Fryrear (1981) state that art therapies can be used to complement verbal therapy. Patients are involved with the arts and creativity. Music has been used for therapy from early times. Music was used to cure the wounded in the World War I. The patients were healed through music while they responded to nothing else. Art therapies have significant role in mental health, rehabilitation and medical field. Arts have been applied for healing. Fleshman \& Fryrear (1981) further add that the Egyptians are said to have encouraged the citizens with mental illness to engage in artistic activities. Music has calming features. Similarly, dance and play are significant to children's health, growth and development.

\section{CONCLUSION}

Art therapy uses painting, drawing, sculpture, music, dance, movement, drama, poetry and creative writing in the context of counseling, psychotherapy, rehabilitation or health-care centers. The focus is not only on the appreciation of artworks but also creation by the individual. Art therapy uses art media, images, imagination and the creative process. Art therapist respects client responses to the created works in terms of personality, interests, abilities, concerns and conflicts. Art therapy attempts to reconcile emotional conflicts, focuses on self-awareness, social skills and behavior. It attempts to address problems by reducing anxiety and pain, and increasing self-respect. In the context of Nepal, art therapy is still a new discipline for study though it has been informally used here and there. Medical field has been highly developed. There are many artists and psychologists. There are also many patients. There is a need of connection 


\section{ART THERAPY: CREATIVITY FOR CURE}

between art, artists, medical field and treatment of patients for effective healing. Aesthetic pleasure can work like the medicine. The process of treatment can be soothing and refreshing like a play. The exploration of art therapy and dissemination of information can address this issue.

\section{WORKS CITED}

Agell, G. (1982). The place of art in art therapy: Art therapy or arts therapy. American Journal of Art Therapy, (21), pp. 15-18.

Aristotle (2009). Tragedy. In S. Lohani, K. C. Sharma, A. Gupto, \&A. Sharma (Eds.), Western intellectual tradition. pp. 13-23. Kathmandu: M. K. Publishers.

Carson, D., \& K. Becker (2004). When lightning strikes: Reexamining creativity in psychotherapy. Journal of Counseling and Development, 82(1), pp. 111-115.

Fleshman, B., \& Fryrear, J. (1981). The arts in therapy. Chicago: NelsonHall.

Freud, S. (1992). Creative writers and daydreaming. In H. Adams (Ed.), Critical theory since Plato. pp. 711-716 New York: Harcourt Brace Jovanovich College Publisher.

Gil, E. (1998). Play therapy for severe psychological trauma [Videotape]. New York: Guilford Press.

Goodenough, F. (1926). Measurement of intelligence by drawings. New York: Harcourt, Brace \& World.

Johnson, D. R. (1985). Envisioning the link among the creative arts therapies. Arts in Psychotherapy, 12 (4), pp. 233-238.

Landreth, G. (1991). Play therapy: The art of relationship. Muncie: Accelerated Development.

Langer, S. K. (2009). Expressiveness. In S. Lohani, K. C., Sharma, A. Gupto, \& A. Sharma (Eds.), Western intellectual tradition. (pp. 189-203) Kathmandu: M. K. Publishers.

Levine, E. (1999). On the play ground: Child psychotherapy and expressive arts therapy. In S. Levine, \& E. Levine (Eds.), Foundations of expressive arts therapy: Theoretical and clinical perspectives. (pp. 257-273). London: Kingsley.

Malchiodi, C.A. (2003). Handbook of art therapy. New York: Guilford.

McNiff, S. (1992). Art and medicine. Boston: Shambhala.

Moreno, J. (1923). Das stegif theater. Berlin: Gustave Kiepenheur.

Pater, W. (1992). Conclusion from studies in the history of the renaissance. In H. Adams (Ed.), Critical theory since Plato. (pp. 640-643). New York: Harcourt Brace Jovanovich College Publisher.

Pennebaker, J.W. (1997). Opening up: The healing power of expressing emotions. New York: Guilford Press. 